\title{
The Nordic Corporate Governance Model
}

\author{
Thomsen, Steen
}

Document Version

Accepted author manuscript

Published in:

Management and Organization Review

DOI:

10.1017/mor.2015.55

Publication date:

2016

License

Unspecified

Citation for published version (APA):

Thomsen, S. (2016). The Nordic Corporate Governance Model. Management and Organization Review, 12(1), 189-204. https://doi.org/10.1017/mor.2015.55

Link to publication in CBS Research Portal

\section{General rights}

Copyright and moral rights for the publications made accessible in the public portal are retained by the authors and/or other copyright owners and it is a condition of accessing publications that users recognise and abide by the legal requirements associated with these rights.

Take down policy

If you believe that this document breaches copyright please contact us (research.lib@cbs.dk) providing details, and we will remove access to the work immediately and investigate your claim.

Download date: 26. Apr. 2023 


\section{The Nordic Corporate Governance Model Steen Thomsen}

Journal article (Post print version)

Cite: The Nordic Corporate Governance Model/Thomsen, Steen. In: Management and Organization Review, Vol. 12, Issue 1, 03.2016, p. 189-204.

Dol: $10.1017 /$ mor.2015.55

Uploaded to Research@CBS: May 2016 
MOR-14-106R

20 June 2015

\title{
The Nordic Corporate Governance Model
}

\section{Steen Thomsen}

Copenhagen Business School, Denmark

\begin{abstract}
The Nordic countries - Denmark, Norway, Sweden, and Finland - have attracted attention in recent years. Some elements of the Nordic model - particularly the welfare state are well understood, but its governance characteristics remain elusive to the international audience. This article reviews Nordic governance and discusses its relevance as a development paradigm. The article quantitatively documents the existence of a Nordic governance model using data from the World Bank, Transparency International and other sources. Secondly, it is shown how Nordic corporate governance - Nordic civil law, concentrated ownership, semi twotier board structures, employee representation and low-powered managerial incentives - has been shaped by the welfare state in ways consistent with systemic corporate governance theories. The article concludes with a skeptical discussion of the Nordic model as a development paradigm.
\end{abstract}




\section{INTRODUCTION}

The Nordic counties ${ }^{[1]}$ have attracted international attention in recent years. Francis Fukuyama (2011; 2014) describes the goal of nation building as 'getting to Denmark'. The UN Global Happiness Index (2013) scores Denmark as number 1 - the happiest country in the world. Oxford Professor Colin Mayer (2012) looks to the Nordic model as an alternative to the AngloAmerican corporation. The Economist (2013) talks about the Nordic Supermodel'. Even Thomas Piketty (2014) argues in favor of Nordic style income redistribution.

Some parts of the Nordic model are reasonably well documented. The Nordic countries are known to be welfare states characterized by large government sectors, strong labor unions, income redistribution, and high taxes (Andersen, Holmström, Honkapohja, Korkman, Söderström, \& Vartiainen, 2007). While the welfare states of the 1960s and 1970s have gone out of fashion, a renewed enthusiasm is now directed at the reformed lean welfare states that have emerged through market discipline, tax reform and restructured government services (The Economist, 2013).

In contrast, the Nordic Corporate Governance model remains less known, at least outside the Nordic countries. Clearly, the business sector must be part of the package, since - for example - the welfare state needs to be financed. Business companies constitute the growth engine of the Nordic model without which it would collapse. Moreover, the governance of Nordic companies has emerged in conjunction with the welfare state and has obviously been influenced by high taxation, income equality, social security and welfare. In this article we examine the corporate governance model that has emerged under these circumstances. The main objective is not to provide a detailed institutional description, which can be found elsewhere (e.g., Conyon \& Thomsen, 2012, chpt. 16), but rather to assess the strengths and weaknesses of 
the model from the viewpoint of countries such as China or India that debate what governance model to adopt in the future.

Even at this early stage, however, a disclaimer is warranted. Fashion waves come and go in political and economic discourse. The fact that the Nordic model is currently popular may have more to do with the perceived failures of dominant models during the 2008-2013 financial crisis than any enduring support for the Nordic way. In particular, the breakdown of the Washington consensus (Williams, 1990) as a recipe for economic development has stimulated a reassessment of the role of government in China and other emerging economies (cf. the discussion of a 'Beijing consensus'). The absence of a universally superior governance model is a recurrent theme in international corporate governance research (e.g., Thomsen \& Conyon, 2012). This will obviously also be true of the Nordic model. What works (or at least appears to work) in the small homogeneous economies of Northern Europe may not be feasible or even desirable in other parts of the world. That said, as Fukuyama observes, those who know only one country knows no country. This article is written on the assumption that there may be lessons learned from comparative governance research and that the Nordic experience constitutes part of the evidence.

\section{THEORETICAL PERSPECTIVES}

The economic literature on governance systems has emphasized the role of formal institutions as determinants of these differences. For example, the law and finance approach associated with La Porta, Lopez-de-Silanes, Shleifer, and Vishny (1998) focuses on the importance of legal origin (common versus civil law) and investor protection for the evolution of capital markets. The implication is that governance systems are rooted in deep seated institutional arrangement and difficult to change. La Porta et al. (1998) point to Nordic (Scandinavian) civil law as a legal 
category which is distinct from German and French civil law and which is associated with generally higher levels of investor protection. Why this would be so is more uncertain; it seems to be more of an observation than a hypothesis.

In contrast, the political theory of corporate governance proposed by Roe $(1991 ; 1994)$ emphasizes the regulation of financial institutions as a source of governance differences. Roe recognizes the existence of lock-in effects attributable to complementarities between institutions and rent seeking to preserve their vested interests (Coffee, 1999; North, 1991; Roe, 1994), but predicts that corporate governance systems will change with changes in the policy. Roe (1994) argues that concentrated ownership emerged in Europe and the Nordic countries as a countervailing force to the power of labor unions.

In a broader sociological perspective, Whitley (1992) regards business systems as 'distinctive ways of organizing economic activities' that 'become established and effective because of major differences in key social institutions, such as the state, the financial system and the education and training system' (13) including labor market organization and 'more general and diffuse attitudes and beliefs about work, material values and authority relations' (16). Whitley's emphasis on labor market institutions is particularly relevant in the Nordic countries where labor unions play an important role.

A similar broad perspective is used by Hall and Soskice (2001), who distinguish between liberal market economies (such as the US or UK) and coordinated market economies (such as Sweden). Hall and Soskice show how the two generic systems differ in terms of industrial relations, training, corporate governance as well as inter-firm and employee relations. With a large government sector, high unionization levels and stakeholder oriented governance the Nordic countries clearly belong to the coordinated market economies. 
Licht (2001) broadens the perspective even further by stressing culture as a determinant of corporate governance. He argues that countries differ systematically in terms of cultural characteristics, such as risk aversion, time horizons, obedience to authority, and other attitudes that influence their choice of corporate governance system. Culturally, according to Hofstede, ${ }^{[2]}$ the Nordic countries are characterized by low power distance (little reliance hierarchy and authority), high levels of individualism and femininity (emphasis on caring and quality of life rather than status and achievement). Moreover, they lean towards low uncertainty avoidance, normativity rather than pragmatism and 'indulgence' (limited self-control), although with some differences so they are not completely culturally homogenous. Nevertheless, it seems plausible for example - that the Nordic welfare state is associated with a high level of femininity although the direction of causality is unclear. Individualism and low power distance might point to low levels of hierarchy, but this seems inconsistent with large government sectors and a disproportionally large number of Nordic multinationals.

The system theories outlined above provide classifications and show how different elements of corporate governance may be related and correlated with general social structures. Thus, they are highly relevant for understanding, how the welfare state -as outlined above and below - has shaped a Nordic 'variety of capitalism'.

However, the system theories are less precise concerning issues causality and systemic change. This makes them less useful for studying the origins of the Nordic model. Why, for example, did the Nordic countries and not the US, Japan, or even Germany develop a welfare state? To understand the origins of the Nordic model it may be necessary to acknowledge the role of human agency as proposed for example by Giddens (1984). Visionary politicians or 
business entrepreneurs may perhaps design systemic change - or they may by coincidence propose institutions that prove to be sustainable over time.

\section{ORIGINS OF THE NORDIC WELFARE STATE}

The system theories outlined above stress the complementarities between governance and other system characteristics. In order to understand Nordic corporate governance, it is important to understand its context, particularly the Nordic social model which has the following main features (Alestalo, Hort, \& Stein, 2009; Andersen et al., 2007):

- A large government sector providing universal access to health care, child care, education etc.

- Significant income transfers including pensions and unemployment benefits

- High taxes rates to finance these expenditures

- Strong labor unions

- Low economic and social inequality

These characteristics are empirically verifiable (Andersen et al., 2007). For example, according to the OECD Nordic tax revenues to GDP are about double the OECD average of $14 \%$ and Nordic unionization is around 66\% (somewhat lower in Norway) against an OECD average of $16 \%$. Inequality is also much lower as documented below.

Ideologically, the Nordic model rests on a combination of social democracy and liberalism. The concept of social democracy (Bernstein, 1899; Sejersted, 2011) revised the radical ideas proposed by socialist philosophers such as Karl Marx. The social democrats dropped the goal of class warfare and violent revolution in favor of a more pragmatic approach 
that eventually came to favor a mixed economy. Communism in turn developed when Lenin (1919) and Mao (1964) broke with social democracy in favor of a more radical approach. Thus the Nordic model has some of the same ideological roots as contemporary China.

It is not difficult to see traces of social democracy in Nordic corporate governance. For example, the idea of employee representation on company boards is clearly related to strong unions. Moreover, other aspects of the welfare state such as the high tax pressure influenced Nordic corporate governance in more indirect ways that we will analyze in the following. However, the Nordic Social Democrats never assumed absolute power. Intermittently, the Nordic countries were ruled by liberal or conservative parties which had also ruled before the social democratic parties got enough votes to form governments. This means that the Nordic model is 'social liberal' rather than purely social democratic. For example, Andersen et al. (2007) point to embracement of globalization as a fundamental building block of the Nordic model.

The Nordic model therefore shares many characteristics with other European countries. In fact most of the basic ideas behind the Nordic model - including social democracy and the welfare state as well as governance arrangements like two-tier boards or employee representation - come from Germany or other non-Nordic countries. Thus imitation rather than innovation is the norm. What makes the Nordic countries special is firstly that these ideas were often more widely used in the Nordic countries than in their countries of origin. The government sector is larger and the tax pressure is higher than in other countries around the world. Possibly, homogenous populations in the smaller Nordic countries enabled them to sustain a higher tax pressure. 
Secondly, governance arrangements were sometimes adapted with a local twist. For example, employees did not get half of the board seats as they do in larger German companies, but only on- third. Such adaptions may have enhanced the efficiency of the Nordic model.

Nordic 'cuddly capitalism' has been criticized by Acemoglu, Robinson, and Verdier (2012), who argue that its dulled incentives stifle innovation and makes it unfit for technology leaders like the US, while it may be sustainable for technology followers. However, Stiglitz (2014) argued that the Nordic emphasis on education and R\&D combined with social security may in fact be conducive to innovation and that this is politically sustainable partly because the gains to innovation are widely shared.

\section{IS THERE A NORDIC GOVERNANCE MODEL?}

Given the qualifications above it is perfectly reasonable to ask if there really is a Nordic governance model. Does such an animal even exist? To be sure, concentrated ownership is not a unique feature, but characteristic of a model of the world outside the US and UK. As for two-tier boards with employee representation this is a German innovation which was imitated by the Nordic countries (and since abandoned in Finland).

To help answer this question, Table 1 below documents the scores of the Nordic countries on the World Bank governance indicators. The high rank of the Nordic countries is notable. They are close to the highest possible average rank of $2.5((1+2+3+4) / 4)$ in many of the governance indicators and way above world averages. Statistical t- and F-tests reveal that the Nordic countries have much better than average corporate governance in all governance dimensions, and for most indicators the difference remain significant after controlling for GDP 
per capita. In other words the Nordic countries have outstanding governance even taking into account their high levels of economic development. ${ }^{[3]}$

\section{[Insert Table 1 here]}

In Table 2 this data is broken down by country/region and corruption data from Transparency International is added. We see the same picture as in Table 1. The Nordic countries rank very highly on both the governance composite and on corruption control - much higher than the US or the EU, which again rank much higher than China and India or the rest of the world. However, Singapore has achieved very high standards in governance and has virtually rooted out corruption.

Interestingly, both China and India have slipped down the scale over time, while the Nordic countries have managed to improve their already substantial lead on other countries. The Euro Area has slipped quite dramatically on corruption (mainly because of enlargement), but even US has slipped a little on both measures. Some of this is no doubt attributable to increasing country coverage over time. But we can reject the hypothesis that the Nordic countries are resting on their laurels based on past achievement and that other countries are catching up as they become richer.

[Insert Table 2 here]

Altogether, the data supports that the Nordic countries are so special in terms of governance that it is reasonable to talk about a Nordic governance model. Whether its corporate governance model is special is less certain.

Thomsen and Conyon (2012) propose that informal governance by social norms should be regarded as part of corporate governance since both formal and informal structures shape 
business behavior. Since issues like corruption or enforcement depend on social norms, Nordic corporate governance is also a special case.

Moreover, even structural elements of corporate governance are likely to be influenced by regulatory quality and the rule of law. We turn to these issues in the next section.

\section{Nordic Corporate Governance}

In this section we examine the Nordic governance model on 4 different criteria: legal system, ownership structure, board structure and executive incentives (i.e., the mechanisms approach suggested by Thomsen \& Conyon, 2012).

The legal system. It is often claimed - e.g., by La Porta et al. (1998) that there is a separate Scandinavian or Nordic branch of civil law - but it is not clear what the special Scandinavian elements are. It is noticeable however that company law in the 4 Nordic countries is very similar and deliberately also since Nordic harmonization was historically considered to be attractive (Hansen, 2003; 2007). Moreover, with top down state law rather than case law Nordic company law is no doubt closer to German civil law than to US/UK common law.

According to the law and finance approach, relatively high investor protection should be associated with large stock markets, but the Nordic stock markets are in fact relatively modest. According to the World Bank (2012), stock market capitalization to GDP varies between 51\% (Norway), 62\% (Finland), 70\% (Denmark) and 103\% (Sweden). This average of 70-80\% may be compared to $115 \%$ in the US and UK - and is no higher than in France (70\%). There may be several reasons for this - for example country size may be a factor - but it is also possible that the welfare state plays a role. Historically most citizens relied on government pension and 
funded pension schemes started to emerge as late as the 1980s. Instead, a large government bond market emerged. Moreover, state ownership was historically important in the Nordic countries except Denmark. Both factors may have lowered the size of Nordic stock markets.

While recognizing the existence of effective minority protection in the Nordics Lekvall et al. (2014) argue that Nordic company law really stands out by providing majority shareholders with relatively unfettered power to control companies, particularly a strictly hierarchical chain of command from the shareholder meeting to the supervisory board and onto the executive management. Majority shareholders face few constraints in replacing supervisory boards, and supervisory boards can freely replace company executives. Majority shareholders or large blockholders often sit on company boards or on nomination committees that nominate directors to the annual general meeting.

Ownership structures in the Nordics vary across countries from bank-based business groups in Sweden to state-owned enterprises in Norway (energy sector), and foundation-ownership in Denmark and Sweden (see below). Outside the publicly listed companies we find a range of cooperatives, mutual and small or medium sized family business. This pluralism has given rise to some skepticism about the concept of a Nordic governance model, but there is little doubt that Nordic governance is based on blockholders rather than market based. Moreover, shareholders have more decision power than in the US/UK and can for example replace the board by simple majority vote at the AGM (Hansen, 2007; Lekvall et al., 2014). However, because of social pressures and/or legal protection of minority investors and stakeholders, large owners appear to be quite well behaved and derive fewer private benefits from ownership than blockholders in the 
US or UK (Coffee, 2001) partly because Nordic countries rank high in enforcement of investor protection.

The most unusual characteristic of Nordic ownership structure is no doubt foundation ownership of business companies (Thomsen, 1996). This structure matters in Denmark and accounts for more than $60 \%$ of total stock market capitalization. It also forms the basis for the two leading business groups in Swedish business (Industrivarden and Wallenberg). Foundation ownership appears to work remarkably well for company performance (Børsting, Kuhn, Poulsen, \& Thomsen, 2014c; Hermann \& Franke, 2002; Thomsen, 1996, 1999; Thomsen \& Rose, 2004). The most direct explanation for the prevalence of this structure in the Nordic is that high wealth taxes made foundations an attractive way for founding families to maintain control. However taxation is probably not all. Both the U.S. and the UK historically had high tax rates (Piketty, 2014) without a correspondingly high formation of industrial foundations. Moreover, the largest and best known industrial foundations like the Carlsberg, Novo Nordisk or A. P. Møller foundations were established before taxation became severe during the 1970s and 1980s. The early formation of Carlsberg and other industrial foundations may be regarded as an example of human agency, which had a lasting distinctive effect on Nordic corporate governance. The charitable nature of foundation ownership may in turn have been helpful in fostering social legitimacy for large companies.

Board structures are quite similar at least in the Scandinavian countries (Denmark, Norway, and Sweden) as a consequence of similarity of company law (Hansen, 2003; Lekvall et al., 2014). There is a distinction between the (supervisory) board and executive management as in Germany, but unlike Germany some limited overlap is allowed between the two levels. 
Moreover, the board is not (as German supervisory boards) limited to supervision but can (as US/UK boards) interfere with whatever it finds appropriate except running the company on a daily basis. For example, unlike the board of statutory auditors in Japan or China or the German supervisory boards, Nordic company boards can easily replace executive managers. The Nordic board structure is therefore usually characterized as semi two-tier (Conyon \& Thomsen, 2012), i.e. there are two tiers, but there is more overlap between the two tiers than in Germany. Note however that Hansen (2007) regards the Nordic board model as essentially one tier, which it historically was.

Like Germany, the 3 Scandinavian countries also have employee representation on company boards, but in an attenuated form with up to $1 / 3$ employees and not up to $1 / 2$ as in Germany. Moreover, unlike in Germany, employee representation is not mandatory but optional to the employees, who often decide not to exercise their rights in small and medium size companies (Thomsen \& Conyon, 2012). Thus Nordic governance is influenced by the stakeholder viewpoint, but not as clearly as in Germany, where employees must elect up to half of the supervisory board in large companies.

Executive incentives are generally less strong than in the US/UK with lower and less variable pay (Thomsen \& Conyon, 2012, p. 290). Differences to the rest of continental Europe are debated but Nordic executive pay is probably in the low end, although this may be attributable to industry structure and pay composition. One reason (as suggested by Piketty, 2014) is that marginal taxes were (and still are) quite high and so that most upward variation in pay is taxed away and companies (or managers) have less of an incentive to set up variable pay systems such as stock 
option schemes. Nevertheless stock options schemes are now quite common and executive pay is rising at the same rates as in the US/UK.

Altogether, the Nordic model has elements of stakeholder governance, which balanced by empowered ownership (Lekvall et al., 2014; Roe, 1994). Ownership structure is concentrated and shareholders are empowered to make decisions. There appears to be less formality and more decentralized decision making than in Germany or the U.S. However, major blockholders may be more sensitive to stakeholder concerns, for example because they have ties to unions (pension funds), government (the Norwegian energy companies) or (as mentioned above) charitable foundations.

The Nordic corporate governance model has obviously developed in conjunction with other elements of Nordic societies. For example, the welfare state and its high tax rates (including historically high wealth taxes) made family business difficult to sustain. Relatively efficient and uncorrupted government has made it less costly to socialize large sector of the economy such as health and education. Roe (2000) speculates that strong owners were necessary to counteract powerful labor unions and thus an essential element of the overall governance system. Coffee (2001) observes that private benefits are lower in the Nordic countries. He argues the small Nordic countries have been able to discipline large owners through social norms, which may be more difficult to do in large heterogeneous countries such as the US or a large stock market with many international issuers and investors such as in the UK.

\section{The Performance of the Nordic Model}

The relative success of Nordic 'cuddly' capitalism shows that it is feasible - under some circumstances - to combine market economy and reasonable growth rates with a large 
government sector, income redistribution and democracy. Its socialist origins conceivably make the Nordic experience interesting for countries with a socialist or communist heritage such as India or China that are themselves going through a transformation to a mixed economy. If social welfare, income equality and happiness are high on the priority list, the Nordic model appears attractive.

In Table 3 we examine how the Nordic countries are doing on alternative measures of economic and social performance.

[Insert Table 3 here]

Nordic GDP per capita is high compared to the US and the rest of Europe, although the U.S. fares better when adjusting for purchasing power parity.

Since 1980, long run economic growth in the Nordics has been at the same level as in other high income OECD countries - slightly higher than EU average, but slightly below the U.S. Obviously, compared to the performance of China, India or Singapore, Nordic growth rates are low, and many would like them to be higher, but they appear to be no lower than in other developed countries. The same trends are observed in stock market indices, which have grown faster in the Nordics than in the rest of continental Europe, but slower than in the U.S.

In terms of perceived happiness the Nordic countries also come out stronger than the benchmark countries and regions. In fact, all of the Nordic countries are in the top 10 of the happiness report. They also come out with low income inequality and high life expectancy (although they have recently been superseded by Singapore on this measure). 
Thus there is some indication that the Nordic model is successful in creating a high quality of life.

However, the Nordic countries are themselves facing challenges that may make their model unacceptable to developing countries. For example, as shown, growth rates have been low in recent years compared to the dynamism of Singapore and other emerging market economies. This has caused much soul searching and reform in the Nordic countries, which are themselves in a period of transition. As The Economist (2013) notes: The streets of Stockholm are awash with the blood of sacred cows'. The reforms include public sector austerity, privatization, outsourcing, public-private partnerships, downsizing and adoption of market principles. It is not clear that the Nordic model is intact or even sustainable in the long run (Kvist \& Greve, 2011).

Moreover, to some extent the Nordic model builds on social capital (trust and cohesion) which is much easier to maintain in small, homogenous and wealthy economies than in large and heterogeneous emerging markets, where poverty remains a serious problem.

As a final point it is interesting to inquire whether high Nordic governance standards have an independent effect on happiness in addition to the effect of a high per capita GDP and whether exceptionally good governance can explain the high level of happiness in the Nordic countries. We explore this possibility in Table 4.

Here, we observe that the Nordic happiness level remains significant even after controlling for both GDP per capita and governance ratings. Moreover governance does not appear to have and a significant direct effect on happiness beyond a potential indirect effect via GDP per capita. Thus, Nordic happiness remains something of a puzzle.

[Insert Table 5] 


\section{The Nordic Model as a Development Paradigm}

Could the Nordic model be a development paradigm for emerging economies like China or India? This seems doubtful for a number of reasons.

First, differences in living standards are very large. GDP per capita in the Nordics is presently 10 times higher than in China and 40 times higher than in India. The welfare state with its generous income transfers and universal welfare provision is costly, and the taxation necessary to finance it could stifle economic growth at a critical stage of development. Differences in government efficiency, levels of corruption and regulatory quality also indicate that large welfare states would run into serious problems in China and India.

Secondly, the Nordic welfare model is quite different from the state capitalism practiced in Singapore or China. Excepting the Norwegian energy sector, Nordic governments are currently mainly involved in welfare services (health, social security, education), while the Singaporean and Chinese governments are active in a range of competitive business.

The Singaporean state-owned enterprises have done remarkably well, partly through good governance (Sim, Thomsen, \& Yeong, 2014), so this might be a more direct source of inspiration. The Nordic governments have over time increasingly withdrawn from ownership of business firms in favor of free (non-market) social services provided free of charge.

Thirdly, both India and China lack the strong labor unions which were the key drivers in Nordic social democracy. Without them, other elements of the Nordic model might be impaired. For example, employee representatives would be at risk of dismissal and so could not function as independent board members.

Finally, the small, homogeneous Nordic countries can rely on shared social norms in a way that might not be possible in large heterogeneous countries like China or India. Such norms 
are difficult to create overnight, and it is not clear that importing Nordic institutions would work in their absence. Chinese or Indian governance will probably need to be founded on domestic traditions and social norms rather than imported cut and paste.

Nevertheless, for what it is worth, we end by considering 3 characteristics of the Nordic model that could provide some inspiration for institutional experiments although they will obviously have to be adapted further to suit the local context.

Employee representation on company boards is perhaps the best direct expression of social democracy on Nordic company boards with the Norwegian gender quota as a possible second. The 1/3 employees on Scandinavian boards is sufficiently far from majority control to make it clear that employee-elected board members primarily have a consultative role while their formal responsibilities (duty of loyalty and care to the company) are the same as those of normal shareholder-elected board members. Perhaps for this reason there has been little organized resistance against it among Nordic employers, while German employers have strongly criticized their brand of codetermination. The consensus view appears to be that Scandinavian employee representation is relatively harmless and perhaps even beneficial in exceptional circumstances such as crisis situations requiring large layoffs. This might be a way to go for Chinese firms, some of which already have employee representation of the statutory board of auditors.

Low and fixed managerial pay is consistent with income equality and attenuated profit incentives imposed by high marginal tax rates and income redistribution in the Nordic countries. Thus, Nordic pay structure have reinforced social democratic ideals without excessive damage to the competitiveness of Nordic companies. In recent decades the Nordic system has been changing, 
marginal tax rates have been lowered by tax reforms, while bonus and stock option schemes have increased variable pay. But it is not clear that China or India necessarily have to imitate the highpowered incentive systems of U.S. listed firms.

Industrial foundations. The survival and success of Nordic industrial foundations raises the issue of whether these structures should be permitted or even encouraged from the viewpoint of economic policy and nation building. At this point, a cautious answer could be that there is no justification for prohibition and that economic policy should aim for tax neutrality and institutional competition so that these entities can be allowed to arise and compete or be outcompeted according to their relative performance. For example, U.S. authorities should probably change the tax rules that have blocked U.S. industrial foundations since 1969 (Thomsen, 2006). Foundation ownership might also be attractive in other contexts, for example it could be an alternative ownership structure for the stock held by the Chinese Academy of Sciences in Lenovo in much the same way that the Danish Academy of Sciences elects the board of the Carlsberg Foundation which owns a controlling share of Carlsberg, the brewery. In fact, industrial foundations may be attractive for Chinese policy makers since they constitute private ownership without private control by investors, entrepreneurs or founding families.

There appears to be three major routes to the creation of industrial foundations:

1. Donation by entrepreneurs (for example to overcome succession problems or avoid high wealth taxes); 2. Conversion of financial mutual, whose equity capital reserves are separated out to foundations before public listing; or 3. Privatization to foundations where a government donates stock in a former state owned enterprise to charitable foundations. 
All three are relevant to institution building in emerging economies. However, the success of foundation creation is likely to depend on context and process. The contrast between the Danish and the Italian experiences is instructive. The privatization of Italian banks appears to have led to inefficiencies as foundation and bank boards were staffed with politicians, while the Danish foundations established by entrepreneurs - and sometime partially governed by members of the founding family - appear to have been better able to retain the efficiency of foundermanagers. The software (board composition) may be just as important as the hardware (ownership structure).

Social capital such as basic levels of trust and honesty, control of corruption, or government efficiency may be a requirement for the success of the foundation structure. Small, homogeneous, and wealthy societies like the Nordic countries may find it easier to fulfill these requirements than large emerging economies that span a wider range of ethic and cultural diversity. Nevertheless, India already knows of foundation-ownership in the Tata group (Thomsen, 2011), and there appears to be no compelling reason why it might not also work in China.

\section{CONCLUSION}

Altogether, while the Nordic model may perhaps provide some useful ideas for social experiments, it is clearly not a blueprint for the development of much larger, less affluent and less homogenous countries like China or India.

\section{NOTES}

[1] The Nordic countries referred to in this article are Denmark, Norway, Sweden, and Finland.

[2] See the relevant country sections at the Hofstede centre: http://geert-hofstede.com/ 
[3] Since governance is believed to have a positive effect on economic growth and GDP per capita, good governance is one reason for high living standards in the Nordic countries, and controlling for GDP per capita may understate Nordic distinctiveness in this areas.

\section{REFERENCES}

Acemoglu, D., Robinson, J. A., \& Verdier, T. 2012. Can't we all be more like Nordics? Asymmetric growth and institutions in an interdependent world. NBER Working Paper 18441, National Bureau of Economic Research.

Alestalo, M., Hort, S. E. O., \& Kuhnle, S. 2009. The Nordic model: Conditions, origins, outcomes, lessons. Working Paper.

Andersen, T. M., Holmström, B., Honkapohja, S., Korkman, S., Söderström, H. T., Vartiainen, J. 2007. The Nordic model - Embracing globalization and sharing risk, Working paper, http://economics.mit.edu/files/5726.

Barton, D., \& Wiseman, M. 2014. Focusing capital on the long term. Harvard Business Review. [Cited 22 June 2015]. Available from URL: https://hbr.org/2014/01/focusing-capital-on-the-long-term

Bernstein, E. 1899. The preconditions of socialism, J. H. W. Dietz, Stuttgart 1899, reprinted. Cambridge: Cambridge University Press.

Børsting, C., Kuhn, J., Poulsen, T., Thomsen, S. 2014a. Industrial foundations as long-term owners. Unpublished Working Paper, The research project on industrial foundations.

Børsting, C., Kuhn, J., Poulsen, T., Thomsen, S. 2014b. The governance of industrial foundations: Executive and director turnover. Unpublished Working Paper, The research project on industrial foundations.

Børsting, C., Kuhn, J., Poulsen, T., Thomsen, S. 2014c. The performance of Danish foundation-owned companies. Unpublished Working Paper, The research project on industrial foundations.

Coffee, J. C. 2001. Do norms matter? A cross-country evaluation. University of

Pennsylvania Law Review, 149: 2151-2177.

The Economist. 2013. The next supermodel. Available from URL: http://www.economist.com/news/leaders/21571136-politicians-both-right-and-left-could-learn-nordiccountries-next-supermodel. Feb 2nd 2013. [Cited 22 June 2015].

Fukuyama, F. 2011. The origins of political order. London, UK: Profile Books.

Fukuyama, F. 2014. Political order \& political decay: From the industrial revolution to the globalization of democracy. New York: Farrar, Strauss \& Giroux.

Giddens, A. 1984. The constitution of society. Berkeley, CA: University of California Press 
Hall, P. A., \& Soskice, D. 2001. Varieties of capitalism. The institutional foundations of comparative advantage. Oxford: Oxford University Press.

Hansen, J. L. 2003. Nordic company law: The regulation of public companies in Denmark, Finland, Iceland, Norway and Sweden. Copenhagen: Djoef Publishing.

Hansen, J. L. 2007. A Scandinavian approach to corporate governance. Scandinavian Studies in Law, 50: $125-142$.

Hansmann, H., \& Thomsen, S. 2012. Virtual ownership and managerial distance: The governance of industrial foundations. [Cited 22 June 2015].]. Available from URL: http://www.tifp.dk/wpcontent/uploads/2011/11/Hansmann-Thomsen-21.pdf

Harvey, J. 1999. Owner as manager, extended horizons and the family firm. International Journal of the Economics of Business, 6: 41-56.

Helliwell, J. F., Layard, R., \& Sachs, J. D. 2014. World Happiness Report. [Cited 22 June 2015].Available from URL: http://unsdsn.org/wpcontent/uploads/2014/02/WorldHappinessReport2013 online.pdf

Hermann, M., \& Franke, G. 2002. Performance and policy of foundation-owned firms in Germany. European Financial Management, 8(3): 261-279.

Kay, J. 2012. The Kay Review of UK equity markets and long-term decision making. Final Report[Cited 22 June 2015]. Available from URL:

http://www.ecgi.org/conferences/eu_actionplan2013/documents/kay_review_final_report.pdf.

Kvist, J., \& Greve, B. 2011. Has the Nordic welfare model been transformed? Social Policy and Administration, 45(2): 146-160.

Lekvall et al. 2014. The Nordic Corporate Governance Model, SNS Förlag, Stockholm, December 2014; Nordic \& European Company Law. Working Paper No. 14-12. Available at SSRN: http://ssrn.com/abstract=2534331.

Lenin V. I. 1919. Founding of the Communist International. Lenin's Collected Works, 4th English Edition, Progress Publishers, Moscow, 1972 Volume 28, pages 480-484. Uploaded to https://www.marxists.org/archive/lenin/works/1919/mar/06.htm.

Mao, T. On Khrushchov's Phoney Communism and Its Historical Lessons for the World:

Comment on the Open Letter of the Central Committee of the CPSU (IX). Foreign Languages Press, Peking 1964. https://www.marxists.org/reference/archive/mao/works/1964/phnycom.htm

Mayer, C. 2013. Firm commitment. Oxford: Oxford University Press.

Piketty, T. 2014. Capital in the Twenty-First Century. Cambridge: Harvard University Press.

La Porta, R., Lopez-de-Silanes, F., Shleifer, A., \& Vishny, R. V. 1996. Law and finance. The Journal of Political Economy, 106(6): 1113-1155. 
Rao, C., \& Thomsen, S. YEAR. Uddelinger og Omkostninger I danske Fonde. Working paper, The Research Project on Industrial Foundations. [Cited DATE]. Available from URL: http://www.tifp.dk/wpcontent/uploads/2011/11/Danske-Fondes-uddelinger-og-omkostninger-VI-12.pdf

Roe, M. J. 2000. Political preconditions to separating ownership from corporate control. Stanford Law Review, 53: 539-606.

Roe, M. J. 2003. Political determinants of corporate governance. Oxford: Oxford University Press.

Sejersted, F. 2011. The age of social democracy: Norway and Sweden in the twentieth century. Princeton \& Oxford: Princeton University Press.

Sim, I., Thomsen, S., \& Yeong, G. 2014. The state as shareholder. The case of Singapore. Center for Governance, Institutions and Organizations. NUS Business School. [Cited DATE]. Available from URL: http://bschool.nus.edu/Portals/0/docs/FinalReport_SOE_1July2014.pdf

Stiglitz, J. E. 2014. Leaders and followers: Perspectives on the Nordic Model and the Economics of Innovation. NBER Working Paper 20493, September 2014.

Thomsen, S. 1996. Foundation ownership and economic performance. Corporate governance: An international review, 4(4): 212-221.

Thomsen, S. 1999. Corporate ownership by industrial foundations. The European Journal of Law and Economics, 7(2): 117-137.

Thomsen, S. 2006. Industrial foundations - foundation ownership of business companies. In K. Prewitt, M. Dogan, S. Heydemann, and S. Toepler (eds.), The Legitimacy of Philanthropic Foundations (pp. 236-251). Russel Sage Foundation.

Thomsen, Steen, Trust Ownership of the Tata Group (December 22, 2011). Available at SSRN: http://ssrn.com/abstract=1976958 or http://dx.doi.org/10.2139/ssrn.1976958.

Thomsen, S. 2012. What Do We Know About Industrial Foundations? Working Paper, The Research project On Industrial Foundations. http://www.tifp.dk/wp-content/uploads/2011/11/What-Do-We-Knowabout-Industrial-Foundations.pdf

Thomsen, S. 2012. Industrial Foundations in the Danish Economy. Working Paper, The Research project On Industrial Foundations. http://www.tifp.dk/wp-content/uploads/2011/11/Industrial-Foundations-andDanish-Society1.pdf

Thomsen, S., \& Conyon, M. 2012. Corporate governance: Mechanisms and systems. McGraw Hill Higher Education.

Thomsen, S., \& Rose, C. 2004. Foundation ownership and financial performance. The European Journal of Law and Economics, 18: 343-364.

Williamson, J. 1990. Latin American adjustment: How much has happened? Institute for International Economics, Conference Volume. Washington, D.C. 
Table 1. Governance indicators in the Nordic countries 1995-2013

\begin{tabular}{|l|l|l|l|l|l|}
\hline & $\begin{array}{l}\text { Nordics } \\
\text { average } \\
\text { rank }\end{array}$ & $\begin{array}{l}\text { Other } \\
\text { countries } \\
\text { average } \\
\text { rank }\end{array}$ & F-test & T-test & $\begin{array}{l}\text { T-test } \\
\text { controlling for } \\
\text { GDP per capita }\end{array}$ \\
\hline Rule of law & 3.6 & 106.1 & $837.31 * * *$ & $29.84 * * *$ & $2.79 * * *$ \\
\hline $\begin{array}{l}\text { Government } \\
\text { effectiveness }\end{array}$ & 4.6 & 104.0 & $658.04 * * *$ & $25.65 * * *$ & $1.94 *$ \\
\hline Regulatory quality & 11.4 & 103.8 & $250.61 * * *$ & $15.83 * * *$ & $0.81 \mathrm{~ns}$ \\
\hline Control of corruption & 4.0 & 104.2 & $662.89 * * *$ & $25.75^{* * *}$ & $2.67 * * *$ \\
\hline $\begin{array}{l}\text { Voice and } \\
\text { Accountability }\end{array}$ & 4.3 & 106.1 & $583.07 * *$ & $24.15 * * *$ & $3.52 * * *$ \\
\hline Political Stability & 14.3 & 104.3 & $219.96 * * *$ & $14.83 * * *$ & $2.13 * *$ \\
\hline Overall Governance & 3.9 & 106.6 & $682.54 * * *$ & $26.13 * * *$ & $2.75 * * *$ \\
\hline
\end{tabular}

Notes: Voice and Accountability: 'The extent to which citizens in a country are able to participate in selecting their government, as well as freedom of expression, freedom of association, and a free media'.

Political Stability and Absence of Violence/Terrorism: 'The perceptions of the likelihood that the government will be destabilized or overthrown by unconstitutional or violent means, including domestic violence and terrorism'. Government Effectiveness: 'The quality of public services, the quality of the civil service and the degree of its independence from political pressures, the quality of policy formulation and implementation, and the credibility of the government's commitment to such policies'.

Regulatory Quality: 'The ability of the government to formulate and implement sound policies and regulations that permit and promote private sector development'.

Rule of Law: 'The extent to which agents have confidence in and abide by the rules of society, in particular the quality of contract enforcement, the police, and the courts, as well as the likelihood of crime and violence'.

Control of Corruption: 'The extent to which public power is exercised for private gain, including petty and grand forms of corruption, as well as "capture" of the state by elites and private interests'.

Overall Governance is a composite measure of the previous measures created by principal component analysis.

Source. World Bank Governance Indicators 2014.

The governance indicators are continuous variables used for F- and T-tests. However for simplicity level differences are show by governance ranking from highest (1) to lowest (215) of maximum 215 countries.

Table 2. Quality of Governance by region

\begin{tabular}{|l|c|c|c|c|c|c|}
\hline & \multicolumn{3}{|c|}{ Governance Rank } & \multicolumn{2}{c|}{ Corruption Control rank } \\
\hline & $\begin{array}{c}1996-2012 \\
\text { Average }\end{array}$ & 1996 & 2012 & $\begin{array}{c}1995-2014 \\
\text { Average }\end{array}$ & 1995 & 2014 \\
\hline Nordics & 3.9 & 4.5 & 3.0 & 4.2 & 5.2 & 3.3 \\
\hline Euro area & 40.3 & 42.1 & 42.8 & 34.0 & 19.7 & 36.9 \\
\hline United States & 21.4 & 18 & 25 & 17.8 & 15 & 17 \\
\hline China & 141.2 & 127 & 144 & 67.0 & 40 & 67 \\
\hline
\end{tabular}




\begin{tabular}{|l|c|c|c|c|c|c|}
\hline India & 114.9 & 102 & 131 & 75.1 & 35 & 85 \\
\hline Singapore & 14.7 & 15 & 12 & 4.9 & 3 & 7 \\
\hline World & 104.6 & 100.5 & 106.5 & 74.6 & 20.9 & 86.6 \\
\hline
\end{tabular}

Notes: Sources: World Bank, Transparency International.

Table 3. Measures of economic and social performance

\begin{tabular}{|l|c|c|c|c|c|}
\hline & $\begin{array}{c}\text { GDP per } \\
\text { capita } \\
\$ 2013\end{array}$ & $\begin{array}{c}\text { GDP per capita } \\
\text { (\% growth) } \\
\text { Average } \\
1980-2013\end{array}$ & $\begin{array}{c}\text { UN } \\
\text { Happiness } \\
\text { Rank } \\
2012\end{array}$ & $\begin{array}{c}\text { Gini } \\
\text { coefficient } \\
\text { (latest) }\end{array}$ & $\begin{array}{c}\text { Life } \\
\text { expectancy } \\
2012\end{array}$ \\
\hline Nordics & 66.282 & 1.7 & 3.8 & 24.4 & 81.0 \\
\hline Euro area & 34.126 & 1.5 & 50.3 & 30.0 & 79.0 \\
\hline United States & 53.142 & 1.8 & 17 & 37.2 & 78.7 \\
\hline China & 6.807 & 8.7 & 91 & 47.6 & 75.2 \\
\hline India & 1.489 & 3.9 & 109 & 49.7 & 66.2 \\
\hline Singapore & 55.182 & 4.5 & 30 & 45.0 & 82.1 \\
\hline World & 6.348 & 1.4 & 77.5 & 37.6 & 63.1 \\
\hline
\end{tabular}

Notes: Source: World Bank Tables 2014, UN (2013)

Table 4. Determinants of happiness

\begin{tabular}{|c|c|}
\hline Model & \\
\hline Dependent Variable & $\begin{array}{l}\text { UN } \\
\text { Happiness } \\
\text { Rank }\end{array}$ \\
\hline Estimation method & $\begin{array}{l}\text { Tobit } \\
\text { regression }\end{array}$ \\
\hline Independent Variables & \\
\hline Nordic country & $\begin{array}{l}-24.07 * * * \\
(7.12)\end{array}$ \\
\hline GDPrank & $\begin{array}{l}0.52 * * * \\
(0.05)\end{array}$ \\
\hline Governance rank & $\begin{array}{l}0.02 \\
(0.06)\end{array}$ \\
\hline Constant & $\begin{array}{l}17.40 * * * \\
(3.81)\end{array}$ \\
\hline F test & $212.10 * * *$ \\
\hline Pseudo R-square & 0.11 \\
\hline $\mathrm{N}$ (country years) & 149 \\
\hline
\end{tabular}

Notes: Standard errors in parenthesis

$* * *=$ significant at $1 \%$ level (t-tests). 
Profile: Steen Thomsen is Professor of Corporate Governance at Copenhagen Business School (CBS) and chairman of the Center for Corporate Governance, CBS. His academic publications include 35 international journal articles and several books on the subject including the McGraw-Hill textbook on "corporate governance: mechanisms and systems" (with Martin Conyon). His research is currently focused on industrial foundations - foundations that own business firms. 
